\title{
Writing as a Way to Form Students' Creativity
}

\section{Удосконалення письма як шлях становлення креативності студентів}

\author{
Oleksandr Nabochuk \\ Ph.D. in Psychology, Rivne Regional Council, Rivne (Ukraine) \\ ORCID ID: https://orcid.org/0000-0002-1448-7687 \\ Researcher ID: http://www.researcherid.com/rid/AAE-4773-2021 \\ E-mail: nab_ol@ukr.net
}

\section{Олександр Набочук}

Кандидат психологічних наук, Рівненська обласна рада, м. Рівне (Україна)

\section{ABSTRACT}

The aim of research is: to distinguish four approaches of defining the essence of creativity depending on which one of the four aspects of this problem is dominant in some a case: the environment in which creative activity is carried out; a creative product; a creative process; a creative person, his/her characteristics.

The following theoretical methods of the research were used to solve the tasks formulated in the article: a categorical method, structural and functional methods, the methods of the analysis, systematization, modeling, generalization.

The results of the research. After analyzing different approaches, we provide the following classification of definitions of creativity:

1) definitions that take into account novelty as the main criterion of creativity. In such a way, we point out that the characteristic "production of something new» is actually included these definitions. However, we'll differently propose

Address for correspondence, e-mail: kpnu_lab_ps@ukr.net Copyright: (c) Nabochuk Oleksandr

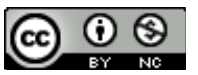


the approaches with the description of the novelty. Thus, we believe that it does not matter whether a society recognizes a certain idea as a new one, but it is important that it has to be new to the creator. On the contrary, we believe that novelty should be fixed in terms of culture, be recognized by contemporaries;

2) definitions in which creativity is opposed to conformity. It includes the definitions, which, contrasting the creativity to conformity, emphasize the importance of bringing originality, a new look at the problem. Such definitions include the understanding of creativity in such a way, when we believe that a creative person is free from both sides - we mean conformism and nonconformism;

3) definitions that focus our attention on the creative process. Thus, we emphasize the importance of creative thinking, and we consider creative thinking as a process of seeing or creating relationships between objects, phenomena, objects on both conscious and unconscious levels. In such a way, we distinguish four stages of the creative process: preparation, incubation, comprehension, review (or analysis). This understanding of creativity is based on any existing method of systematic training of subjects in the process of creative thinking;

4) the definitions that emphasize the importance of developing mental abilities of the person. We define creativity in a view of the development of mental abilities of the individual, which in such a way provides creative achievements in the process of the person's activity. According to this, creative thinking includes divergent products in its structure, which, in turn, contribute to the generation of new, original, unusual and perhaps unique informational levels based on this standard, well-known paradigm of information. However, creative thinking is not reduced to divergent one, because it also implies a person's sensitivity to problems, the ability to reorient.

Conclusions. We proposed the approach based on determining the levels of creativity which are developed by writing. We offered the following levels of creativity: a) expressive creativity - for example, spontaneous drawing by children; b) productive creativity - scientific and artistic products; c) inventive creativity, when ingenuity is manifested in materials, methods and techniques; d) innovative creativity - improvement through modification; e) generating creativity - the formulation of a completely new principle or assumption around which new ideas, concepts, theories and schools may arise.

Key words: writing, students' creativity, a creative product, a creative process, a creative person, levels of creativity, expressive creativity, productive creativity, inventive creativity, innovative creativity, generating creativity.

(c) Nabochuk Oleksandr

DOI (article): https://doi.org/10.32626/2227-6246.2021-53.212-234 


\section{Introduction}

Writing is a very important skill in our daily life. It helps us in realizing communication among people in social communities. It also plays a significant role in the process of language development, learning and teaching. Therefore, teaching communicative skills is important particularly to learners of English as for foreigners. However, writing instruction involves different challenges that need to be taken into account. There may be so many problems in writing by students. It's a pity, but a great many problems are unsolved in scientific literature. Firstly, we've to tell about the problem of the development of the person's creativity. This problem is relevant at the English lessons. We'll try to explain our point of view.

English learners' mistakes should be analyzed carefully because these mistakes show the process of learning a language. The learners' mistakes are very important providing the insight into how far a learner has progressed in acquiring a language and showing how much more the learner needs to study (Гончарук \& Онуфрієва, 2018; Онуфрієва, 2020). Traditionally, writing is defined as the paper-based modality; however, many writings nowadays are happening through computer-based medium. Today's learners use computers such as a tool for learning, and teachers have to adopt the use of different technologies to be taught.

So, the aim of research is: to distinguish four approaches of defining the essence of creativity depending on which one of the four aspects of this problem is dominant in some a case: the environment in which creative activity is carried out; a creative product; a creative process; a creative person, his/her characteristics.

\section{Methods of the research}

The following theoretical methods of the research were used to solve the tasks formulated in the article: a categorical (c) Nabochuk Oleksandr

DOI (article): https://doi.org/10.32626/2227-6246.2021-53.212-234 
DOI: https://doi.org/10.32626/2227-6246.2021-53

2021. ВипУСК 53

method, structural and functional methods, the methods of the analysis, systematization, modeling, generalization.

\section{Results and their discussion}

From the one side, among four main types of speech activity (speaking, reading, listening and writing) the first three ones are recognized as contemporary teaching methods of foreign languages in a way of studying by students different subjects. From the other side, writing the letter is considered only as a mean of mastering the first three types of speech activity. Therefore, in practice, in the educational process, writing is not always given due attention. Among many teachers there is a misconception that writing is developing according to oral characteristics. However, scientists have also noted that one should not hope that in a way of mastering the mechanism of writing, written skills will become as rich and developed as oral speech, and will be similar to a written type of the translation according to the original (Amabile, Conti, Lazenby \& Herron, 1996).

In accordance with psychologists (Collins \& Amabile, 1999), written speech is characterized by a number of peculiarities. First of all, it is necessary to note the abstractness of written speech, which manifests itself in two aspects: the first one is when written speech is speech "in thought», "by presentation", speech, having been deprived of the most significant sign of oral speech - «material sounds». Secondly, writing is a speech «without a companion», hence it requires more consciousness, it has to be thought out and planned. That's why some scientists noticed that the partner of communication and even "the silent listener» helps to regulate oral speech. A direct contact with the speaker helps to identify misunderstanding (Onufriieva, 2017). The reaction of the listener arbitrarily directs the speaker, making him/her to stay by one or another aspect of speech in more details, explaining the peculiarities

(c) Nabochuk Oleksandr

DOI (article): https://doi.org/10.32626/2227-6246.2021-53.212-234 
DOI: https://doi.org/10.32626/2227-6246.2021-53

2021. випуск 53

or characteristics of oral or written speech. The person who writes must independently determine such a way of constructing a statement that makes it more understandable to the reader (Mykhalchuk \& Kryshevych, 2019).

The abstractness of oral speech causes one main its peculiarity - consciousness, hence more attention to the selection of lexical-grammatical devices, syntactic organization of sentences and composition of the whole text. Psychologists (Івашкевич \& Гудима, 2020) also oppose oral and written speech by a great number of parameters. We will restrict ourselves to indicate only those ones which are the most significant in the aspect of our article.

The specificity of oral speech, if compared with the written one, is that a speaker (a listener) has a whole complex of extra-linguistic factors that are deprived by the person who writes (reads): intonation, pauses, voice modulation, facial expressions and pantomime, auto-correction and others. From this point of view situational and conditional dependence of the speech is given by the oral statement of the implicit (hidden) semantic background, which in the written language can be expressed only through lexical-grammatical means.

Written speech, the main characteristics of which determine the absence of the partner of communication, is therefore maximally deployed, in which the syntactical dismemberment reaches its highest maximum. By writing, due to the lack of partners of communication, it is rarely possible for understanding from the half-word, from predicative words or word-combinations. In written speech there are different situations, which exclude the possibility of having a common purpose in students' thoughts. Therefore, written speech in this aspect in its comparison with the oral one, maximally has been expanded and complicated form of speech looking at syntax, by which it is necessary to use a much larger number of words than in oral speech for the expression of the person's individual thought.

(C) Nabochuk Oleksandr

DOI (article): https://doi.org/10.32626/2227-6246.2021-53.212-234 
The analyses of the psychological features of the generation (perception) of written speech and the linguistic features of its design are necessary for the organization of the effective educational process. In our opinion, only speech that from the both sides corrects (corresponding to accepted linguistic and psycho-linguistic norms), becomes rich (diverse from the side of use of lexical and grammatical constructions), and coherent (logical, sequential, having pauses, syntactically incomplete units, etc.). These characteristics can be considered to be well-developed. In order to form the abilities of students on this level of speech, it is necessary to organize such forms of the activity, which simultaneously provide a great improvement of students' skills of registration and content-filling of their own written statements. Such form of the written activity is creative in general, from a side of a lot of characteristics. That's why, if to show writing as a creative type of the activity, it is possible to develop creativity of students as a personal capability.

To our mind, mistakes are no longer perceived as something bad or inappropriate in teaching or learning a language and in such a way that should be deleted in any reason. On the contrary, mistakes have become a necessary component of the educational process, because they in a great degree develop students' thinking and their creativity. And even more, there is a special type of linguistic analysis that focuses students' attention on those mistakes made by them. We define the mistakes in the analysis as means of identifying, classifying and systematically interpreting inappropriate forms of speech activity taken by those students who study a foreign language. That's why we can further argue that correcting mistakes is a procedure used both by researchers and teachers having been involved in collecting forms of the activities of perceiving the linguistic material having been studied, identifying mistakes, classifying them by types and reasons, and their different characteristics. In some situations we can argue that the (c) Nabochuk Oleksandr DOI (article): https://doi.org/10.32626/2227-6246.2021-53.212-234 
DOI: https://doi.org/10.32626/2227-6246.2021-53

2021. випуск 53

mistakes can be performed for different purposes: a) to know how well someone knows the language; b) to understand how a person learns the language; c) to get information about the typical difficulties of learning a language. The method of analysis of language mistakes in the written forms of the activity, performed by students, is useful for developing students' creativity.

To prove this mind we can give some examples. In such a way, in the researches (Boden, 1991) it was proposed the analysis of mistakes made by students whose native language is not English (Japanese, Chinese, Burmese, French, Czech, Polish, Tagalog, Maori, Malaysian, most of Indian and West African languages), without comparing them among themselves. So, the scientist analyzed the sources of mistakes in the process of studying of a foreign language. Also he identifies 1007 mistakes in the process of writing English texts by 50 Czech students.

According to these results, we'll say that with the aim to develop students' creativity it is useful to study mistakes in a foreign language. It is important from different points of view for students of different social groups. Firstly, the mistakes are important as for students so for teachers. Analyzing mistakes, the teacher studies how students not only make a great progress in learning, but also how they show their creativity. In this way, one can see that they still need to study, discover and confirm the strengths and weaknesses of the curriculum. If a teacher understands that it is difficult to master the language and why the mistakes can be, a student will be able to spend more time in the classroom organizing practical exercises on this or that subject. Also the analyses of mistakes can thus provide a significant support of the learning process of students. Secondly, mistakes provide invaluable «live» information according to the learning process and language proficiency, emphasizing on the methods and strategies that students use by the way to study a foreign language. Third(c) Nabochuk Oleksandr

DOI (article): https://doi.org/10.32626/2227-6246.2021-53.212-234 
DOI: https://doi.org/10.32626/2227-6246.2021-53

2021. випуск 53

ly, the mistakes will be useful for students in the process of self-development of their creativity and self-knowledge. The ability to analyze own mistakes, the understanding of their mistakes and their analysis provide the learning mechanisms for students. If students understand that some material is difficult for them to learn, they will pay more attention, do such kind as grammatical inflections, not only by a way of training but also in the process of natural speech. We should remember that analysis of students' own is not the method of an evaluation - it is a method of help or facilitation.

Understanding both the teacher and the student, typical mistakes and their subsequent analysis determine the further steps of both a partner of communication in learning process. Among them there are the main ones: the development of ways to correct typical mistakes, the preparation of a number of mistakes in a foreign language and speech tasks for exercising at classes and at home, the choice of choosing a textbook of a corresponding level of language, the development of strategies for learning the second language. Some representatives of the Theory of the mistakes' analysis see the differences between «language mistakes» and «language flaws». For example, we define "a language mistake» as a systematic deviation from the chosen norm or set of rules. "Language mistakes» allow a pupil to gain new knowledge of the rules of the language, which is incomplete, perhaps because they were influenced by the linguistic system of their native language.

Language mistakes can be divided into receptive and productive ones. Receptive mistakes are those ones arising from misunderstanding of the intentions by the student (a speaker). There are also productive mistakes - those ones that facilitate the expression of each student. Also we indicate local and global language mistakes. Local ones do not interfere with the whole process of communication and they do not prevent general comprehension of the statement. Global mistakes are, on the one hand, more serious than local ones, because global mis-

(c) Nabochuk Oleksandr

DOI (article): https://doi.org/10.32626/2227-6246.2021-53.212-234 
DOI: https://doi.org/10.32626/2227-6246.2021-53

2021. випуск 53

takes interfere with global social communication and violate the content of each statement in such a way. Local mistakes have a deal with the use of different forms of a noun and a verb, with the use of articles, prepositions and auxiliary verbs. Global mistakes may also be considered the wrong order of words in the sentences and apply to all levels of the language system: phonological, morphological, lexical, and syntactic ones. In turn, language flaws are random deviations, not fixed to any language system, and, unlike global linguistic mistakes they are done not systematically and in the same way. Language flaws may have various evidences and varieties, such as in the form of refusals, distortion of the heard information, wrong start, the lack of agreement between the subjective and the predicate types of connections in the long complex sentences. The example of a language flaw can be the case when a student who knows the difference between «a man» and «a woman» and when he/she acquainted with pronouns, uses «she» in the meaning of "a man». We think that language flaws have a place in writing and in oral speech as a result of carelessness, fatigue, inattentiveness and others.

That's why we have to draw our attention to the fact that it is necessary to distinguish openly false statements - those ones which are obviously grammatically incorrect, and hidden false statements, which are grammatically correctly used, but they are incomprehensible in the context of communication. In addition to the typology of mistakes, long-term researches organized by us in this area suggest that there are several main reasons for mistakes in learning a foreign language. The first reason is interference of a native language, or interlingual translation, which is a negative influence of a native language. The native language of students plays the important role in learning of a foreign language. The process of translation from the native to a foreign language is one of the causes of written mistakes. This happens because the student tries to translate the sentences from the native language to the foreign one lite(C) Nabochuk Oleksandr

DOI (article): https://doi.org/10.32626/2227-6246.2021-53.212-234 
DOI: https://doi.org/10.32626/2227-6246.2021-53

2021. ВИПУСК 53

rally. This is probably the most common mistake, for example, when we have a deal with the translation of idioms.

Mistakes having been done under the influence of the native language are called inter-lingual/intra-lingual. The second reason relates to intramuscular factors of language development. Intra-lingual mistakes and language development mistakes depend on the severity of the second language having been studied. The reason for the correction of mistakes can be the terms or the context in which the foreign language is studied. For example, we mean the situation when a class is with a teacher, teaching linguistic materials, in a case of studying at school or solving social situations in a case of learning a foreign language by students' own. In a case of classroom management, a teacher or a tutor can contribute to the student's misconception about a foreign language. Another example is the student's loss of motivation to study because the materials and/or a style of students' submission are not appropriate to each person, and, as a result, there is a lack of attention to the learning process in general. Of course, such educational process can not be creative.

The fourth reason for possible mistakes is the prevalence of communicative strategies, which involves the conscious use of verbal mechanisms for the expression of the idea without a particular linguistic form that is inaccessible to each student for some reasons. These reasons are noted by us by some expressions:

1. Simplification: students often choose simple examples and design some information instead of more complex activities, for example, using Present Simple instead of Present Continuous in English.

2. Generating or preparing creative tasks. Students often choose one form or design some material in a creative context and transfer it to another context where there is no need to be used without understanding the components (parts) of phrases or sentences. Creative language is pleasant for tourists, filled 
DOI: https://doi.org/10.32626/2227-6246.2021-53

2021. випуск 53

with borrowed phrases, most of which there are phrases, where some expressions and phrases are grouped from different points of view, according to different models.

3. Avoidance (syntactical, lexical, phonetic, thematic creative tasks). Some students are difficult to use some structures. As a result, these students avoid using these structures and use simpler ones instead of the first structures. For example, in the lexical structure "I lost my way", the student avoids the use of the word "way» and says instead of it «I said I'd lost my road».

The example of phonological avoidance is the fear of misunderstanding a word and, as a result, this student is a liar, there is a substitution that "He does not speak the truth». In a case of «thematic avoidance» to avoid the main subject the student may change the subject of conversation, pretend that he does not understand it, or just does not answer at all.

4. False assumptions: many mistakes of students can be caused by a false assumption of a foreign language. For example, some students think that the word "as" is an indicator of the present day. Therefore, they express themselves in such a way: «He talks as the teacher».

In the other example the verb "was» is an indicator of the past. Based on this frame we'll say: "It was happened last night». The model of mistakes' analysis includes three stages:

1) data collection - a sample of the language body, written or oral one, the identification of mistakes, their type of classification and numerical representation. Traditionally, written forms of the activity of students in large groups were selected for some samples. For example, a letter is shown a reproductive skill. Students have time to systematize their knowledge and can clearly show areas of incomplete knowledge. For example, after the first written assignment, the teacher will be able to understand that a half of the students do not understand the use of capital letters, so this material may be included later. These are such skills, as: listening and reading are difficult to (c) Nabochuk Oleksandr

DOI (article): https://doi.org/10.32626/2227-6246.2021-53.212-234 
DOI: https://doi.org/10.32626/2227-6246.2021-53

2021. випуск 53

identify some mistakes, as the causes of these mistakes are not obvious;

2) a qualitative description of mistakes includes a comprehensive analysis of each mistake and a source of its origin;

3) conclusions are the explanation of various types of mistakes, taking into account the various factors which influenced their occurrence. The theory of mistakes' analysis was extremely useful for deeper understanding of language mistakes that students admit. This was a useful approach that encouraged further research and the development of new theories. However, it was not without disadvantages. Firstly, our Theory of Mistakes' Analysis takes into account only some main cases of incorrect use of different forms of mistakes. However, the student does not take into account at least two things. One of them is the correction of forms that a student uses. Mistakes themselves can not provide accurate information about what the student actually knows. Secondly, as the student progresses in learning the language, he/she produces the ability to avoid problem structures. Students can count very few mistakes in the meaningful of subordinate sentences by the examples of other students. According to further analysis it may be clear that the student simply does not try to use these subordinate sentences in general - rightly or wrongly. Students who know that they are having difficulties with such structures can look for different ways to avoid their use. The prospect of further intelligence is the study of the traditions and the current state of Ukrainian pedagogical science teaching foreign language by the definition and the analysis of language mistakes, the study of contemporary linguistics for the identification and the analysis of language mistakes.

In such a way let us present common mistakes in students' writing activities in English.

\section{Affect / Effect}

- Affect is a verb, for example: «Sometimes, the weather affects my mood».

(C) Nabochuk Oleksandr

DOI (article): https://doi.org/10.32626/2227-6246.2021-53.212-234 
DOI: https://doi.org/10.32626/2227-6246.2021-53

2021. випуск 53

- Effect is a noun, for example: «The effect of weather on ice-cream sales is well documented».

Thinking in terms of «the effect» you can usually determine whether to use «affect» or «effect» since «the» will not put in front of a verb.

To add to the confusion, bear in mind that some people may use "effect» as a verb (for example, «Contractors seek to effect a settlement with strikers») but this usage is slightly archaic and the most often they are used in legal writing.

Apostrophes

However, by learning few simple rules and the inevitable exceptions, you should be able to use apostrophes.

The apostrophe is used for a purpose, either to indicate a possession (implying ownership) or a contraction (in a place of other letters). Since its use to indicate a contraction is easiest, we will deal with this case.

Using Apostrophes to Indicate Contraction

Where one or more letters have been dropped, an apostrophe is used as a replacement:

- it is = it's;

- we are = we're;

- does not = doesn't;

- of the clock = o'clock.

Using Apostrophes to Indicate Possession

Apostrophes are also used to indicate possession:

- Matthew's car.

- The farmer's field (one field owned by one farmer).

If the subject (the farmer or Matthew above) has a name ending with «S», then there is a choice to either follow the formal rule («The Jones's house») or to drop the final «s» (such as «The Jones' house»). The choice is a matter of style but the important thing is to be consistent.

If the subject is plural, the apostrophe is placed after «S»:

- The teachers' staff room.

(c) Nabochuk Oleksandr

DOI (article): https://doi.org/10.32626/2227-6246.2021-53.212-234 
- The farmers' fields (multiple fields having been owned by multiple farmers).

We've to note that if the word is already plural, for example «children» or "people», then you would write «children's» or «people's».

When we do not Use Apostrophes

If the word is a plural then we do not use «s» after the apostrophe (for example, kittens' - only the apostrophe). Placing an apostrophe before the final «S» is universally considered incorrect and commonly referred to as the "greengrocer's apostrophe» (or «greengrocers' apostrophe» if referring to more than one greengrocer).

There are possible exceptions to these rules if the word comprises a single letter, a number or abbreviation where the simple addition of «S» could cause confusion. For example: There are two «t's» in Matthew.

To write "There are two ts in Matthew» may confuse the reader even though it is grammatically correct. Alternatively, you could rephrase this, as: "There are two «t's in Matthew».

However, the contemporary convention is to avoid using apostrophes in plurals wherever it is possible even in the plural of numbers and abbreviations.

For example: «I keep buying DVDs» and «He loves 80s music» is preferable to adding an apostrophe.

\section{Could have / Should have / Would have}

Even though we might pronounce «could've» (a contraction of «could have») as "could of» - this is incorrect. Always use could have / should have / would have.

\section{It's / Its}

- It's is a contraction of two words: it is or it has.

- Its is possessive, like "hers», "his», and "whose».

The confusion between «it's» and «its» takes a place, because by virtually every other word «'s» (the apostrophe $+s$ ) which indicates possession, so English speakers naturally want to use «it's» to mean «something is belonging to it».

(C) Nabochuk Oleksandr

DOI (article): https://doi.org/10.32626/2227-6246.2021-53.212-234 
DOI: https://doi.org/10.32626/2227-6246.2021-53

2021. випуск 53

But «it's» is only used when it is a contraction of «it is» or «it has».

If you are in doubt as to which version to use, we'll try replacing the word with «it is» or «it has». If this still scans correctly then use «it's», otherwise, use «its».

There / Their / They're

- There refers to a place or the idea. The example of «there» is when we use referring to place «it is»: «Look over there!» The example of «there is (are)» is used when it is referring to an abstract idea: "There are many ways to skin a cat».

- «Their» has possessive meaning when someone owns something, for example: «Their dog keeps getting into our garden».

- «They're» is a contraction of «they are» (the apostrophe replaces the missing letter). The example of "they're» is used: "They're moving to the next door».

There's / Theirs

- «There's» is a contraction of «there is».

- «Theirs» is the third person plural, the possessive pronoun which replaces «their + noun». The idea shows that there's a need to emphasize the context be the apostrophe (hence "there's»), derives from the convention that, in virtually every other word, "s» (apostrophe $+\mathrm{s}$ ) indicates possession. However, theirs is an exception and «their's» is incorrect.

To / Too / Two

«To» has two functions. Firstly, it is a preposition and it is always preceded by a noun, for example:

- I am going to the shops.

- This belongs to Mary.

Secondly, «to» indicates an infinitive when it is preceded a verb, such as:

- I need to sleep.

- He wants to go for a walk.

«Too» also has two ways of using, the first is as a synonym for «also», for example:

(C) Nabochuk Oleksandr

DOI (article): https://doi.org/10.32626/2227-6246.2021-53.212-234 
DOI: https://doi.org/10.32626/2227-6246.2021-53

2021. ВИПУСК 53

- Can I come too?

- I think that's his bag too.

Secondly, «too» means excessively when it is preceded by the adjective or the adverb:

- I'm too tired to go out.

- You're too generous.

The most common confusion is between «to» and «too". Try to replace the word with «also» or "as well» and if the phrase makes sense then we use «too». Otherwise, if it is not a number, we use «to».

Let us show Frequently Misused Words. Some words there are in the meaning of "Decimate».

«Strictly», "decimate» mean «to reduce by one-tenth» or «not to reduce by one-tenth». However, this usage is now increasingly common, and seems likely «to become accepted».

In some cases the word phrases are used in the meaning of "Literally». "Literally» means «actually» or «without exaggeration». When you say «I literally...» you are describing something exactly as it is happened without exaggeration. If you were to say "I literally died of boredom» you are implying you actually are died and the use of "literally» is therefore incorrect.

\section{Lose / Loose}

«Lose» is the opposite of «win», while «loose» is the opposite of «tight» or «contained».

Weather / Whether

«Weather» is usually a noun referring to the atmospheric conditions at a particular point in time (What's the weather like there?), but it is also a verb with the meaning affected by the weather (for example: "Your fence has really weathered») or even as a figure of speech means «to get through" or "to survive something», for example: («We weathered the crisis»).

"Whether» is a conjunction that introduces alternatives, for example: «Whether I win or lose...» or «You do it whether

(C) Nabochuk Oleksandr

DOI (article): https://doi.org/10.32626/2227-6246.2021-53.212-234 
DOI: https://doi.org/10.32626/2227-6246.2021-53

2021. випуск 53

you like it or not». "Whether» is similar to «if», so if you could replace the word with «if», then use «whether».

After analyzing different approaches, we provide the following classification of definitions of creativity:

1) definitions that take into account novelty as the main criterion of creativity. In such a way, we point out that the characteristic «production of something new» is actually included these definitions. However, we'll differently propose the approaches with the description of the novelty. Thus, we believe that it does not matter whether a society recognizes a certain idea as a new one, but it is important that it has to be new to the creator. On the contrary, we believe that novelty should be fixed in terms of culture, he recognized creativity by contemporaries;

2) definitions in which creativity is opposed to conformity. It includes the definitions, which, contrasting the creativity to conformity, emphasize the importance of bringing originality, a new look at the problem. Such definitions include the understanding of creativity in such a way, when we believe that a creative person is free from both sides - we mean conformism and nonconformism;

3) definitions that focus our attention on the creative process. Thus, we emphasize the importance of creative thinking, and we consider creative thinking as a process of seeing or creating relationships between objects, phenomena, objects on both conscious and unconscious levels. In such a way, we distinguish four stages of the creative process: preparation, incubation, comprehension, review (or analysis).

This understanding of creativity is based on any existing method of systematic training of subjects in the process of creative thinking;

4) the definitions that emphasize the importance of developing mental abilities of the person. We define creativity in a view of the development of mental abilities of the individual, (C) Nabochuk Oleksandr

DOI (article): https://doi.org/10.32626/2227-6246.2021-53.212-234 
which in such a way provides creative achievements in the process of the person's activity. According to this, creative thinking includes in its structure divergent products, which, in turn, contribute to the generation of new, original, unusual and perhaps unique informational levels based on this standard, well-known paradigm of information. However, creative thinking is not reduced to divergent one, because it also implies a person's sensitivity to problems, the ability to reorient.

\section{Conclusions}

Also we proposed the approach based on determining the levels of creativity which are developed by writing. We offered the following levels of creativity: a) expressive creativity - for example, spontaneous drawing by children; b) productive creativity - scientific and artistic products; c) inventive creativity, when ingenuity is manifested in materials, methods and techniques; d) innovative creativity - improvement through modification; e) generating creativity - the formulation of a completely new principle or assumption around which new ideas, concepts, theories and schools may arise.

\section{Literature}

Гончарук Н., Онуфрієва Л. Психологічний аналіз рівнів побудови комунікативних дій. Psycholinguistics. Психолінгвістика. Психолингвистика, 2018, 24 (1), 97-117. URL : https://doi.org/10.31470/ 2309-1797-2018-24-1-97-117.

Івашкевич Е., Гудима O. Psychological ways of the development of intercultural competence of pupils in the field of «Foreign Language Education" (according to the experience of education in foreign countries). Збірник наукових пращь «Проблеми сучасної психолоzï̈», 2020, 49, 84-105. URL : https://doi.org/10.32626/2227-6246. 2020-49.84-105.

Онуфрієва Л.А. Розвиток професіоналізму майбутніх фахівців соціономічних професій: соціально-психологічний вимір: монографія. Київ : Видавець Бихун В.Ю., 2020. 320 с. ISBN 978-617-7699-08-7. Amabile, T.M., Conti, H., Lazenby, J., \& Herron, M. Creative environment at work. Academy of Management Journal, 1996, 36, 1154-1184.

(C) Nabochuk Oleksandr

DOI (article): https://doi.org/10.32626/2227-6246.2021-53.212-234 
DOI: https://doi.org/10.32626/2227-6246.2021-53

2021. випуск 53

Boden, M.A. The creative mind: myths and mechanisms. New York : Basic Books; London : Abacus, 1991. $171 \mathrm{p}$.

Collins, M.A., \& Amabile, T.M. Motivation and creativity. Handbook of Creativity. R. Sternberg (Ed.). Cambridge, 1999. P. 297-313.

Mykhalchuk Nataliia, Kryshevych Olga. The peculiarities of the perception and understanding of Sonnets written by W. Shakespeare by the students of the Faculty of Foreign Languages. Psycholinguistics. Психолінгвістика. Психолингвистика, 2019, 26 (1), 265-285. URL : https://doi.org/10.31470/2309-1797-2019-26-1-265-285.

Onufriieva, L.A. The Psychology of Professional Realization of a Future Specialist's Personality: Theoretical and Methodological Aspect. Monograph. Rzeszów : BonusLiber, 2017. 194 s. ISBN 978-83-6544183-6.

\section{References}

Honcharuck, Nataliia, \& Onufriieva, Liana. (2018). Psykholohichnyi analiz rivniv pobudovy komunikatyvnykh dii [Psychological analysis of levels of communicative actions' constructing]. Psycholinguistics. Psykholinhvistyka. Psikholingvistika - Psycholinguistics. Psycholinguistics. Psycholinguistics, 24 (1), 97-117. Retrieved from https:// doi.org/10.31470/2309-1797-2018-24-1-97-117 [in Ukrainian].

Ivashkevych, E., \& Hudyma, A. (2019). Psychological ways of the development of intercultural competence of pupils in the field of «Foreign Language Education" (according to the experience of education in foreign countries). Zbirnyk naukovykh prats "Problemy suchasnoi psykholohii» - Collection of scientific issues "Problems of modern Psychology», 49, 84-105. Retrieved from https://doi.org/10.32626/ 2227-6246.2020-49.84-105.

Onufriieva, L.A. (2020). Rozvytok profesionalizmu maibutnikh fakhivtsiv sotsionomichnykh profesii: sotsialno-psykholohichnyi vymir [The development of the professionalism of future specialists of socionomic professions: socio-psychological aspect]. Kyiv : Publisher Bykhun V.Yu. ISBN 978-617-7699-08-7.

Amabile, T.M., Conti, H., Lazenby, J., \& Herron, M. (1996). Creative environment at work. Academy of Management Journal, 36, 1154-1184.

Boden, M.A. (1991). The creative mind: myths and mechanisms. New York : Basic Books; London : Abacus.

Collins, M.A., \& Amabile, T.M. (1999). Motivation and creativity. Handbook of Creativity, (pp. 297-313). R. Sternberg (Ed.). Cambridge.

Mykhalchuk, Nataliia, \& Kryshevych, Olha (2019). The peculiarities of the perception and understanding of Sonnets written by W. Shake-

(C) Nabochuk Oleksandr

DOI (article): https://doi.org/10.32626/2227-6246.2021-53.212-234 
DOI: https://doi.org/10.32626/2227-6246.2021-53

2021. ВИПУСК 53

speare by the students of the Faculty of Foreign Languages. Psycholinguistics. Psykholinhvistyka. Psikholingvistika - Psycholinguistics. Psycholinguistics. Psycholinguistics, 26 (1), 265-285. Retrieved from https://doi.org/10.31470/2309-1797-2019-26-1-265-285.

Onufriieva, L.A. (2017). The Psychology of Professional Realization of a Future Specialist's Personality: Theoretical and Methodological Aspect. Rzeszów : BonusLiber. ISBN 978-83-65441-83-6.

\section{Набочук Олександр. Удосконалення письма як шлях становлення креа- тивності студентів}

\section{АНОТАЦІЯ}

Мета дослідження - виокремити чотири підходи до визначення сутності творчості залежно від того, який із чотирьох аспектів цієї проблеми є у даному випадку домінуючим: середовище, у якому здійснюється творча діяльність; творчий продукт; творчий процес; творча особистість, її характеристики.

Для розв'язання поставлених у роботі завдань використано такі теоретичні методи дослідження: категоріальний, структурно-функціональний, аналіз, систематизація, моделювання, узагальнення.

Результати дослідження. Проаналізувавши різні підходи, ми пропонуємо таку класифікацію визначень творчості:

1) визначення, що враховують новизну як основний критерій творчості. Зокрема, можемо вказати, що характеристику «продукування чогось нового» фактично включено у иі визначення. Однак, до опису самої новизни ми підходимо по-різному. Так, ми вважаємо, що зовсім не важливо, чи визнає суспільство певну ідею новою, а важливим є те, щоб вона була новою для самого твория. Також ми вважаємо, що новизна повинна фіксуватися в термінах культури, тобто визнаватися сучасниками;

2) визначення, у яких творчість протиставляється конформності. До них належать визначення, які, протиставляючи творчість конформності, наголошують на значущості привнесення оригінальності, нового погляду на проблему тощо. До таких визначень відноситься й розуміння творчості, яке передбачає, що творча людина звільнена як від конформізму, так і від нонконформізму;

3) визначення, що орієнтуються на творчий процес. Так, ми наголошуємо на важливості для людини творчо мислити й розглядаємо творче мислення як процес бачення чи створення взаємозв'язків між предмета-

(C) Nabochuk Oleksandr

DOI (article): https://doi.org/10.32626/2227-6246.2021-53.212-234 
ми, явищами, об'єктами як на свідомому, так і на несвідомому рівнях. Ми виокремлюємо чотири етапи творчого процесу: підготовка, інкубація, осягнення, перегляд (або аналіз). Відтак, в основу становлення креативності покладено будь-який існуючий метод систематичного навчання суб'єктів творчому мисленню;

4) визначення, які наголошують на важливості розвитку розумових здібностей людини. Так, ми визначаємо творчість з огляду на розумові здібності особистості, що забезпечує творчі досягнення у прочесі діяльності. Отже, творче мислення вміщує у своїй структурі дивергентну продукцію, що, своєю чергою, сприяє породженню нової, оригінальної, незвичайної, а, можливо, й унікальної інформації на основі стандартної, добре відомої інформачії. Однак, творче мислення не зводиться до дивергентного, адже воно також має на увазі чутливість людини до проблем, здатність до переорієнтування тощо.

Висновки. Отже, ми запропонували рівні творчості, що формуються в особистості внаслідок становлення здатності до письма. Ми пропонуємо такі рівні творчості: а) експресивна творчість - наприклад, спонтанне малювання дітьми; б) продуктивна творчість - наукові та художні продукти; в) інвентивна, або винахідницька, творчість, коли винахідливість проявляється в матеріалах, методах і техніках; г) інноваційна творчість - покращення шляхом модирікації; д) творчість, що породжує - формулювання абсолютно нового принципу чи припущення, навколо якого можуть виникнути нові ідеї, концепції, теорії та школи.

Ключові слова: письмо, творча діяльність студентів, творчий продукт, творчий прочес, творча особистість, рівні творчості, експресивна творчість, продуктивна творчість, інвективна творчість, інновачійна творчість, творчість, що породжує.

\section{Набочук Александр. Совершенствование письма как путь становления креативности студентов}

\section{АННОТАЦИЯ}

Цель исследования - выделить четыре подхода к определению сущности творчества в зависимости от того, какой из четырех аспектов этой проблемы является в этом случае доминирующим: среда, в которой осуществляется творческая деятельность; творческий продукт; творческий процесс; творческая личность, ее характеристики.

(C) Nabochuk Oleksandr

DOI (article): https://doi.org/10.32626/2227-6246.2021-53.212-234 
DOI: https://doi.org/10.32626/2227-6246.2021-53

2021. випуск 53

Для решения поставленных в работе задач использованы следующие теоретические методы исследования: категориальный, структурнофункциональный, анализ, систематизация, моделирование, обобщение.

Результаты исследования. Проанализировав различные подходы, мы предлагаем следующую классификацию определений творчества:

1) определения, учитывающие новизну как основной критерий творчества. В частности, можем указать, что характеристика "делания чего-то нового» фактически включена в эти определения. Однако, к описанию самой новизны мы подходим по-разному. Во-первых, мы считаем, что совсем не важно, признает ли общество определенную идею новой, а важно, чтобы она была новой для самого творца. Во-вторых, мы считаем, что новизна должна обязательно фиксироваться в терминах культуры, т. е. признаваться современниками;

2) определения, в которых творчество противопоставляется конформности. К ним относятся определения, которые, противопоставляя творчество конформности, подчеркивают значимость привнесения оригинальности, нового взгляда на проблему. К таким определениям относится и понимание творчества, которое предусматривает, что творческий человек является освобожденным как от конформизма, так и от нонкондормизма;

3) определения, ориентирующиеся на творческий прочесс. В статье подчеркнута важность для человека творчески мыслить. Мы рассматриваем творческое мышление как процесс видения или создания взаимосвязей между предметами, явлениями, объектами как на сознательном, так и на бессознательном уровнях. Мы выделяем четыре этапа творческого процесса: подготовка, инкубация, постижение, анализ. В основу становления креативности, таким образом, может быть положен любой существующий метод систематического обучения субъектов творческому мышлению;

4) определения, которые подчеркивают важность развития умственных способностей человека. Мы определяем творчество как процесс, учитывающий умственные способности личности, что обеспечивает творческие достижения в прочессе деятельности. Таким образом, творческое мышление содержит в своей структуре дивергентную продукцию, что, в свою очередь, способствует порождению новой, оригинальной, необычной, а, возможно, и уникальной информации на основе стандартной, хорошо известной информации. Однако, творческое

(C) Nabochuk Oleksandr

DOI (article): https://doi.org/10.32626/2227-6246.2021-53.212-234 
DOI: https://doi.org/10.32626/2227-6246.2021-53

2021. ВИПУСК 53

мышление не сводится к дивергентному, ведь оно также подразумевает чувствительность человека к проблемам, способность к переориентации и $\partial p$.

Выводы. Были предложены уровни творчества, которые формируются у личности в результате становления способности к письму. Мы предлагаем следующие уровни творчества: а) экспрессивное творчество - например, спонтанное рисование детьми; б) продуктивное творчество - научные и художественные продукты; в) инвентивное, или изобретательское, творчество, когда изобретательность проявляется в материалах, методах и техниках; г) инновационное творчество - улучшение через модификацию; д) порождающее творчество - формулирование совершенно нового принципа или предположения, вокруг которого могут возникнуть новые идеи, концепции, теории и школы.

Ключевые слова: письмо, творческая деятельность студентов, творческий продукт, творческий процесс, творческая личность, уровни творчества, экспрессивное творчество, продуктивное творчество, инвективное творчество, инновационное творчество, порождающее творчество.

Original manuscript received April 18, 2021 Revised manuscript accepted May 31, 2021 